\title{
FACTORS INFLUENCING INCREASING INTEREST IN TECHNICAL EDUCATION
}

\author{
Michaela AŽALTOVIČOV $\boldsymbol{A}^{*}$, Univerzita Konštantína Filozofa v Nitre, \\ Slovenská republika \\ Viera TOMKOVÁ, Univerzita Konštantína Filozofa v Nitre, \\ Slovenská republika
}

Přijato: 9. 7. 2019/ Akceptováno: 16. 12. 2019

Typ článku: Teoretická studie

DOI: $10.5507 /$ jtie.2019.012

Abstract: The paper reflects the partial results of the inquiry focused on the pupils of primary schools and the factors that influence their interest in technical education. Despite the high demand from employers for technically skilled graduates of secondary vocational schools and universities, the interest of pupils in technical professions and technical education continues to decline. This is despite the research that shows that science perceives science (natural science) and technology positively because it realizes that science and technology make their lives more comfortable and easier.

Key words: technical education, increasing interest, technic, education, profesional orientation of pupils

\section{FAKTORY OVPLYVŇUJÚCE ZVYŠOVANIE ZÁUJMU O TECHNICKÉ VZDELÁVANIE}

Abstrakt: Prispevok je reflexiou čiastkových výsledkov šetrenia zameraného na žiakov základných škôl a faktorov, ktoré najviac vplývajú na ich záujem o technické vzdelávanie. Napriek vel'kému dopytu zo strany zamestnávatel'ov po technicky zdatných absolventoch stredných odborných škôl a vysokých škôl, záujem žiakov o technické profesie a technické vzdelávanie stále klesá. Je to aj napriek výsledkom výskumov ktoré ukazujú, že mládež vníma vedu (prírodné vedy) a techniku pozitívne, pretože si uvedomuje, že veda a technika robí ich život komfortnejším a jednoduchším.

Klíčová slova: technické vzdelávanie, zvyšovanie záujmu, technika, vzdelávanie, profesijná orientácia žiakov

\footnotetext{
*Autor pro korespondenci: michaela.azaltovicova@ukf.sk
} 


\section{1 Úvod}

Vol'ba povolania je v živote človeka jedným z dôležitých medzníkov v procese vývinu. Každý človek má určité potreby, ktoré tvoria základnú formu motivácie, tak aby sa tieto počas života napíňali. Ide o potreby psychické, medzi ktoré patrí aj potreba učenia, zdokonal'ovania sa a vzdelávania.

Z vol'by profesie sa buduje sociálna pozícia v spoločnosti, spoločenská prestíž a životný štýl, ktorý je zvyčajne prepojený s preferenciou určitých hodnôt, záujmov a celkového nasmerovania (Holeček, 2015).

\section{Technické vzdelávanie v kontexte spoločnosti}

Podl'a Stratégie popularizácie vedy a techniky v spoločnosti (2008), kde sa uvádzajú výsledky vzt’ahu verejnosti k vede a technike, je problém vnímania vedy a výskumu nových technológií celoeurópskym problémom. Je vel'mi dôležité pre celú spoločnost' venovat' pozornost' technike. Vzdelávanie v technike a záujem mladých l'udí o vedecko-technickú kariéru značne klesá. Podl’a informačného portálu Ministerstva školstva, vedy, výskumu a športu Slovenskej republiky vo vzdelávaní a príprave na profesionálnu kariéru je potrebné zatraktívnit' a sprístupnit' vedu a techniku žiakom. Je potrebné vybavit' základné a všetky typy stredných škôl potrebnými modernými technickými vyučovacími prostriedkami a laboratóriami. Národný projekt „Podpora polytechnickej výchovy na základných školách“ je zrkadlový projekt zložený z dvoch častí - Konvergencia a Regionálna konkurencieschopnost' a zamestnatel'nost' (http://www.rokovania.sk/appl/material.nsf/0/4DAB9E3E97434015C12572750038C05A /\$FILE/Zdroj.html).

Projekt nadväzuje na úspešný národný projekt „Podpora profesijnej orientácie žiakov základných škôl na odborné vzdelávanie a prípravu prostredníctvom rozvoja polytechnickej výchovy zameranej na rozvoj pracovných zručností a práca s talentami“, čím umožnil rozšírit' skupinu podporených základných škôl a zámer zatraktívnit’ a zvýšit' kvalitu vyučovacieho procesu v oblastiach zameraných na polytechnickú výchovu.

Ciel’om národného projektu bolo a je zvýšenie záujmu žiakov základných škôl o predmety zamerané na polytechnickú výchovu, rozvoj pracovných zručností žiakov hlavne voblastiach vzdelávania predmetov fyziky, techniky, biológie a chémie a z toho vyplývajúca podpora profesijnej orientácie žiakov základných škôl na odborné vzdelávanie a prípravu. Prioritou aktivít národného projektu bolo skvalitnit' a zatraktívnit' vyučovací proces prostredníctvom vybavenia odborných učební chémie, fyziky, biológie, techniky s využitím moderných metód a foriem vzdelávania, aby sa mohla uskutočnit' obsahová prestavba vzdelávania na základných školách a pripravit’ absolventa pre aktuálne a perspektívne potreby trhu práce (http://pvodborne.sk/).

Ciel’om predkladaného príspevku je nájdenie a popísanie faktorov, ktoré najviac ovplyvňujú žiakov pri výbere technického vzdelávania na stredných školách a popísanie faktorov, ktoré ovplyvňujú zvyšovanie záujmu o technické vzdelávanie u žiakov.

Na podporu polytechnickej výchovy a profesijnej orientácie bol na Slovensku realizovaný národný projekt, ktorý poznáme v skrátenom názve projekt Dielne 1 a Dielne 2. Projekt sa zameriava na alarmujúcu situáciu a jej riešenie ohl’adom rozhodovania žiakov základných škôl pri výbere ich budúceho povolania, výbere budúcej kariéry a s tým spojeným rozhodnutím o výbere strednej školy. Momentálny trend pri výbere d’alšieho 
stredoškolského štúdia je taký, že žiaci uprednostňujú výber štúdia so všeobecným zameraním, ktoré ich však nepripravuje na výkon konkrétneho povolania v budúcnosti. Na trhu práce absentujú kvalifikovaný pracovníci pre prácu v priemysle a výrobnej sfére. Problematika profesijnej orientácie žiakov základných škôl je v rámcovom vzdelávacom programe zahrnutá vo vzdelávacej oblasti Človek a svet práce. Spomína už v štátnom vzdelávacom programe ISCED 1 pre primárne vzdelávanie. Žiaci by mali získat' základné zručnosti v rôznych oblastiach l'udskej činnosti. Predmet Pracovné vyučovanie sa zameriava na tvorivé využívanie technických materiálov, starostlivost' o životné prostredie či na prípravu jedál a l’udové remeslá a tradície. Na druhom stupni základnej školy sa v tejto vzdelávacej oblasti kladie priorita na vzt’ah k práci a otázky výberu povolania.

\section{Výsledky prieskumu}

Obsahom predkladaného príspevku je predstavenie výsledkov prieskumu realizovaného na siedmych základných školách v Slovenskej republike. Do prieskumu boli zapojené základné školy z nasledujúcich miest: Radošina, Motešice, Trebišov, Stupava, Bytča, Spišská Stará Ves a Zvolen. Žiakom bol predložený dotazník s osemnástimi položkami, ktoré obsahovali otvorené a zatvorené otázky a otázky s 5 stupňovým škálovaním. Celkovo sa do prieskumu zapojilo 311 žiakov, z toho 157 chlapcov, 153 dievčat a jeden žiak pohlavie neuviedol. Návratnost' dotazníkov z celkového rozdaného počtu dotazníkov 360 bola $86,4 \%$.

V nižšie uvedených grafoch môžeme vidiet' výsledky niektorých položiek z dotazníka, ktorý bol predložený žiakom.

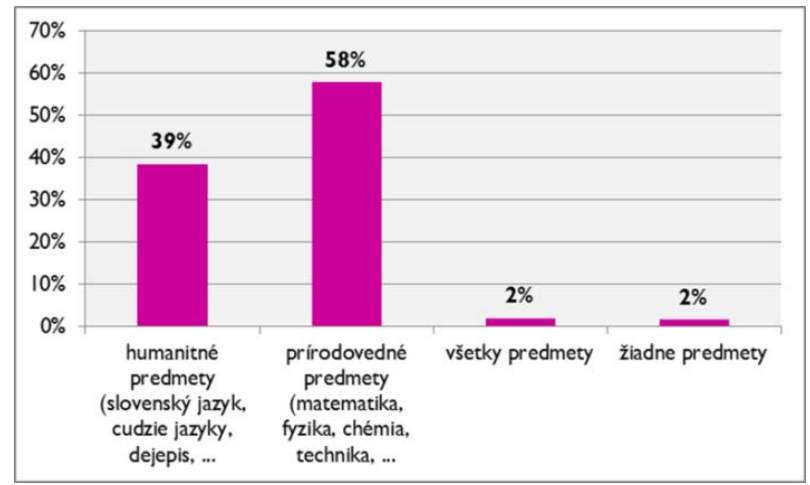

Graf 1 - Preferencie záujmu o vyučovacie predmety.

Vyhodnotenie prvého grafu predstavuje preferencie žiakov o jednotlivé okruhy vyučovacích predmetov. 58 \% žiakov uviedlo, že sú pre nich zaujímavejšie prírodovedné predmety, medzi ktoré zarad’ujeme matematiku, fyziku, chémiu, či techniku. Čo potvrdzujú aj predošlé výskumy o pozitívnom vnímaní prírodovedných predmetov žiakmi. O humanitné predmety prejavilo záujem 39 \% opýtaných žiakov. $2 \%$ žiakov označilo ako svoju možnost', že sa im páčia všetky predmety a 2 \% žiakov, že sa im nepáčia žiadne predmety. 


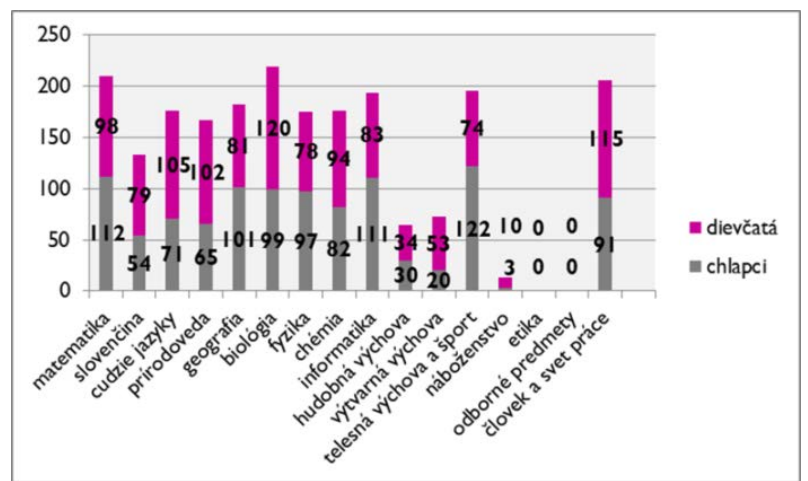

Graf 2 - Preferencie zobrazujúce oblúbenost' jednotlivých predmetov rozdelené aj podla pohlavia žiakov.

Na grafe 2 môžeme vidiet' preferencie žiakov základných škôl zapojených do prieskumu a ich obl'úbenost' jednotlivých predmetov aj s rozdelením podla pohlavia žiakov. Za najviac oblúbený predmet vybrali žiaci biológiu. Až 219 žiakov z 311 opýtaných uviedlo biológiu medzi svojimi najobl'úbenejšími predmetmi. Z hl'adiska pohlavia biológiu zvolilo za svoj najoblúbenejší predmet najviac dievčat. V počte 120 zo 153 zúčastnených dievčat v prieskume. Čo sa týka oblúbenosti u dievčat, na druhom mieste sa umiestnila vzdelávacia oblast' Človek a svet práce, do ktorej zarad'ujeme aj techniku. Zaujímavé je, že táto oblast' bola viac obl'úbená u dievčat ako u chlapcov, v pomere 115 dievčat ku 91 chlapcom. U chlapcov sa medzi najoblúbenejšie predmety zaradila matematika, ktorú si vybralo 98 chlapcov. Je zaujímavé, že ani jeden žiak neoznačil predmet etika a odborné predmety. $\mathrm{Na}$ prvých priečkach $\mathrm{v}$ oblúbenosti predmetov sa nám objavili všetko prírodovedné predmety, čo nám aj potvrdzuje výsledky predchádzajúcej položky z dotazníka o väčšej obl'úbenosti prírodovedných predmetov u žiakov základných škôl.

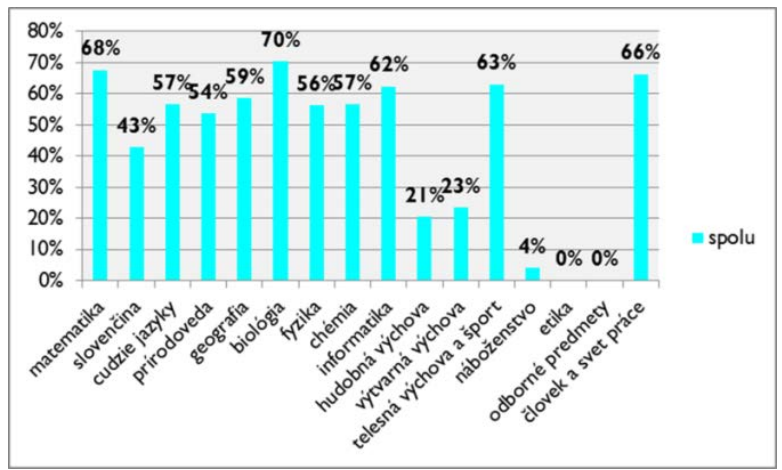

Graf 3 - Percentuálne zobrazenie oblúbenosti jednotlivých predmetov.

Percentuálne zobrazenie v grafe 3 vyjadruje obl'úbenost' jednotlivých predmetov. Ako sme už spomínali vyššie, medzi najoblúbenejšie predmety u žiakov patria predmety 
prírodovedného charakteru a to biológia (70 \% opýtaných žiakov), matematika (68 \% žiakov) a vzdelávacia oblast' Človek a svet práce, ktorú si v prieskume zvolilo 66 \% žiakov.

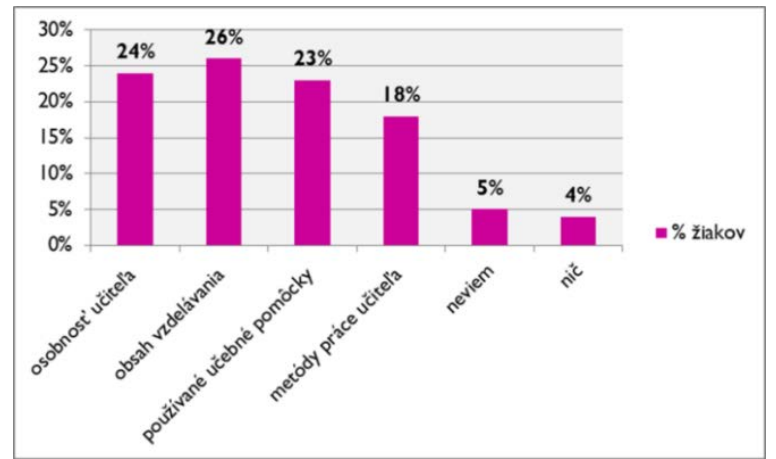

Graf 4 - Výsledok vplyvov pri rozhodovaní výberu strednej školy.

Vyššie uvedený graf 4 ukazuje vyhodnotenie položky Čo ovplyvnilo Tvoje rozhodnutie pri výbere strednej školy? Žiaci mohli uviest' aj viac možností. Ako najčastejšiu možnost' žiaci označili obsah vzdelávania (26\%), osobnost' učitel'a (24 \%) a používané učebné pomôcky (23 \%). Medzi jednotlivými položkami nie je vidiet' signifikantnejšie rozdiely, je preto zrejmé, že najviac žiakov ovplyvňujú pri výbere ich budúceho štúdia všetky tri faktory zároveň. Na základe uvedeného môžeme tvrdit', že žiakov najviac ovplyvňuje vo vyučovacom procese obsah vzdelávania, osobnost' učitel'a a učebné pomôcky, ktoré používa. To znamená, že spôsob formy vyučovania, ktoré využíva učitel' žiaci pokladajú za najdôležitejšie pri ich formovaní záujmu o d’alšie vzdelávanie v príslušnom odbore. Učitel' by sa mal snažit' o správnu atmosféru v triede, dobrú komunikáciu so žiakmi a zatraktívnenie obsahu vzdelávania.

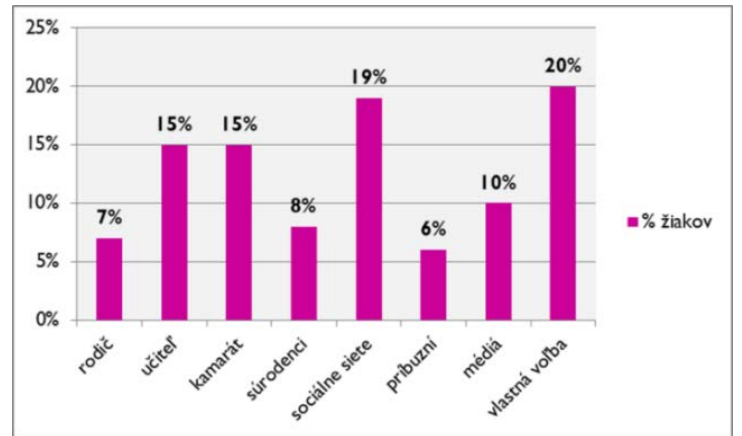

Graf 5 - Výsledok ostatných faktorov vplývajúcich na žiakov pri výbere strednej školy.

Graf 5 zobrazuje percentuálne zastúpenie jednotlivých odpovedí položky, ktorou sme sa žiakov pýtali aké d’alšie faktory ich ovplyvnili pri výbere strednej školy. 20 \% žiakov 
odpovedalo, že to bola ich vlastná vol'ba, 19 \% žiakov ovplyvnili sociálne siete. Zhodne po $15 \%$ žiakov odpovedalo, že to bol kamarát, alebo učitel'. Tieto d’alšie tri položky najviac ovplyvnili žiakov pri ich rozhodovaní o výbere strednej školy. Je zaujímavé, že iba $7 \%$ žiakov odpovedalo, že ich pri výbere strednej školy ovplyvnil rodič. Vieme, že sú to práve rodičia, ktorí zvyknú najviac ovplyvnit' pri výbere d’alšieho štúdia svoje deti.

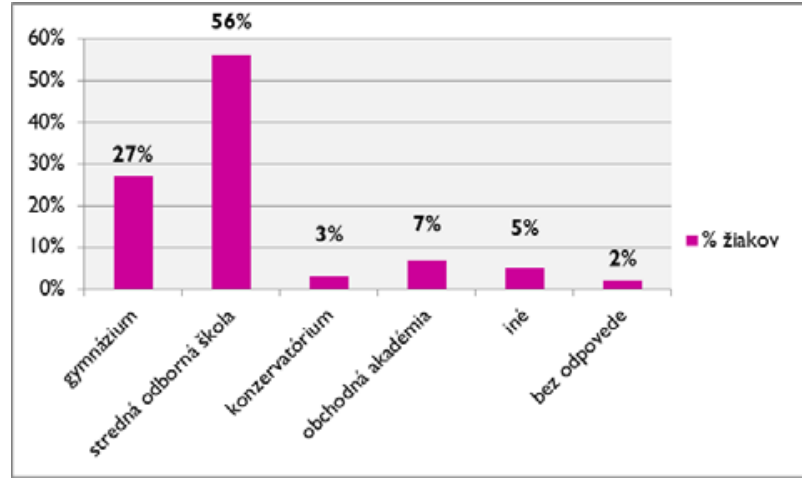

Graf 6 - Percentuálny podiel výberu strednej školy.

Graf 6 zobrazuje percentuálny podiel' vol'by výberu strednej školy u žiakov, ktorý sa zúčastnili prieskumu. Až $56 \%$ opýtaných žiakov uviedlo, že pre svoje d’alšie štúdium majú v plane si vybrat' strednú odbornú školu. 27 \% žiakov si vybralo gymnáziu a iba

7 \% obchodnú akadémiu, 5 \% niečo iné, $3 \%$ konzervatórium a $2 \%$ žiakov na túto otázku neodpovedali. Môžeme preto vidiet', že je významný rozdiel' v percentách žiakov s výberom strednej odbornej školy a gymnázia. Žiaci sa chcú vo svojom d’alšom vzdelávaní orientovat' vo väčšej miere na špecifické povolanie, na ktoré ich pripraví stredná odborná škola. Pri výbere možnosti strednej školy mali žiaci uviest' aj aký odbor si chcú zvolit'. Najčastejšími možnostami boli odbory: elektrotechnik, technik IKT, technik, drevárstvo, zdravotníctvo, umelecké smery. Uvedené v poradí od najfrekventovanejšieho.

\section{Záver}

Na základe vyhodnotenia vybraných položiek konštatujeme, že žiaci základných škôl majú záujem o vzdelávaciu oblast', ktorej súčast'ou je vyučovací predmet technika. Žiaci, ktorí si vybrali strednú školu technického zamerania, označili možnost', že ich pri výbere najviac ovplyvnil obsah vzdelávania. Bola to ich vlastná vol'ba alebo ich ovplyvnili sociálne siete. V porovnaní s najnovším výskumom (Pavelka a kol., 2019) realizovanom v tomto roku na vzorke 2199 žiakov základných škôl ôsmeho a deviateho ročníka, najväčšie percento žiakov (62,35 \%) pri výbere strednej školy ovplyvnili rodičia. Rodinné prostredie vo vel'kej miere vplýva na žiakov či už v pozitívnom alebo negatívnom zmysle. Vel'ký vplyv při výbere strednej školy majú aj vol'nočasové aktivity žiakov. Podl'a Pavelku a kol. (2019) iba 1,96 \% žiakov trávi svoje vol'ný čas aktivitou zameranou na techniku 
alebo manuálne činnosti. V tomto smere môžeme vidiet' nepriaznivý vplyv rodinného prostredia na žiakov z pohl'adu ich technického smerovania.

Správny výber strednej školy je pre žiakov dôležitý. Vhodne zvolená stredná škola môže žiaka dobre pripravit' na výkon budúceho povolania $\mathrm{v}$ technických odvetviach a ovplyvňuje aj jeho budúce spoločenské postavenie. V súčasnosti je na trhu práce nedostatok technických pracovníkov, preto je dôležité začat' vzdelávat' deti v oblasti techniky nie len na primárnom stupni vzdelávania, ale už na tom predprimárnom, t.j. v materských školách. Deti si tak osvoja manuálne zručnosti, ktoré im môžu pomôct' pri výbere ich budúcej profesijnej orientácie, ale pomôžu im rozvíjat' také zručnosti a danosti, ktoré sú pre nich potrebné. Rozvoj manuálnych zručností detí a žiakov vedie $\mathrm{k}$ aktivite žiakov, ich motivácií a napomáha pri budovaní si vzt’ahu k technike a tým aj k technicky orientovaným predmetom.

\section{Bibliografia}

Ažaltovičová, M., Depešová, J. (2018). Aplikácia výsledkov projektu Dielne v technickom vzdelávaní na základnej škole. Banská Bystrica, Slovenská republika: Časopis technika a vzdelávanie, Univerzita Mateja Bela v Banskej Bystrici.

Dostál, J. - Prachagool, V. (2015). Technology Education at a Crossroads - History, Present and Perspektives, Journal of Technology and Information Education, 8(2), DOI: 10.5507/jtie.2016.006.

Holeček, V. (2015). Psychologie v učitelské praxi. Praha: Grada.

http://pvodborne.sk/

Inovovaný ŠVP pre základné školy. (2015). In: Ministerstvo školstva, vedy, výskumu a športu Slovenskej republiky. [online]. [cit. 2019-05-30] http://www.minedu.sk/inovovany-svp-pre-zakladne-skoly/

Kozík, T. (2013). Zmeny a perspektívy technického vzdelávania vo vzdelávacej oblasti Človek a svet práce, Technika a vzdelávanie 2(2).

Krušpán, I. a kol. (1999). Technická výchova pre 5. až 9. ročník základných škôl. EXPOL Pedagogika, s. r. o.

Lukáčová, D. (2009). Postoje žiakov ZŠ k technickému vzdelávaniu, in Technické vzdelávanie ako súčast' všeobecného vzdelávania, Banská Bystrica: UMB, s. 277-281; Záhorec, J., Hašková, A., Munk, M., Bílek, M (2015). Tertiary Economy and Managerial Study Fields and Issues of Science Education Aimedat Database Systems, in Journal of Baltic Science Education, 14 (4), s. 535-555.

Lukáčová, D., Bánesz, G. (2007). Premeny technického vzdelávania. Nitra: Pedagogická fakulta UKF.

Mareš, J. (2013). Pedagogická psychologie. Praha: Portál, s.r.o.

Národný projekt podpora polytechnickej výchovy na základných školách [online].

Pavelka, J. a kol. (2019). Interest of primary school pupils in technical activities and technical education. Plzeň: Západočeská univerzita v Plzni.

Petlák, E. et al. (2011). Kapitoly zo súčasnej edukácie. Bratislava: Iris.

Průcha, J., Walterová, E., Mareš, J. (2009). Pedagogický slovník. Praha: Portál, s.r.o

Stratégia popularizácie vedy a techniky v spoločnosti. (2018). [online]. http://www.rokovania.sk/appl/material.nsf/0/4DAB9E3E97434015C12572750038C05A/ \$FILE/Zdroj.html 